\title{
Influence of Repeated Oscillation Stress in Rats
}

\author{
Satoru KOZIMA and Masahide KATO \\ Central Research Laboratories, Yomeishu, Seizo, Co., Ltd., 2132-37 \\ Nakaminowa, Minowa-machi, Kamiina-gun, \\ Nagano 399-46, Japan
}

(Received 18 February 1983 / Accepted 25 May 1984)

\begin{abstract}
The influence of two weeks of repeated oscillation stress on rats was investigated. Organ weights, liver glycogen, adrenal ascorbic acid, hematological and serum biochemical analysis and maximum contraction of vas deferens induced by noradrenaline were measured. In stress-loaded rats, body weight fell to 85-90\% compared with control rats. Atrophy of the thymus and hypertrophy of the adrenals were found in stress-loaded rats. Hematological and serum biochemical findings revealed that white blood cells and blood glucose decreased, but NEFA increased significantly. Serum sodium increased, but potassium decreased. Maximum contraction of vas deferens induced by noradrenaline was potentiated in stress-loaded rats. The other findings did not differ from those of controls. From these results, it is suggested that the stress-loaded rat shows some abnormalities, but may adapt partially to stress.
\end{abstract}

ラットにおける振盪ストレス反復負荷の影響

小島 暁 ・加藤正 秀

養命酒製造 (株) 中央研究所

遺伝的な背䜿をもつ病態動物の開発はもとより，何ん らかの実験操作により機能異常を伴った病態動物を作成 することは，薬効検定のうえから重要なことと考えられ る。

Takagi et al. [1] は疲労の病態モデルとして振璗ス トレス負荷マウスを利用し，木下ら $[2]$ も振洫ストレス 負荷による消化吸収障害マウスを報告している。また,

著者らは振㴧ストレス負荷ラットの掑食障害 [3] および 消化管分泌機能障害 [4]を観察している。

今回, 著者らはこの振燙ストレス負荷ラットの病態動 物としての性格を明らかにするため，2週間にわたり 1 日 3 時間の振蕰ストレスを反復負荷し, その臟器重量, 血液像, 血清生化学值, 肝グリコーゲン量, 副腎アスコ
ルビン酸量および輸精管の薬物反応性を検討した。

Wistar 系雄性ラット（体重約 $230 \mathrm{~g}$, 静岡県実験動物 農業協同組合）を 2 週間の予備飼育後，アクリル製の拘 束箱に一匹づつ入机，振幅 $13.5 \mathrm{~cm} ， 1$ 分間に 130 往復の 条件で14:00から17:00までの 3 時間にわたり左右の振壍 運動を負荷した。その後金網ケージに戻し，固型飼料 （オリエンタルMF）扰び水道水を与えた。ストレス 負荷中の室温は $19^{\circ} \mathrm{C}$, それ以外は $23^{\circ} \mathrm{C} と し$, 照明時間 は6:00から18:00までとした。このストレス負荷を 2 週 間反復し, 最終ストレス負荷後18～19時間の安静時にエ ーテル軽麻酔下で腹大動脈より採血した。解剖後ただち に臟器重量, 肝グリコーゲン量 (Anthron 法) および副 腎アスコルビン酸量 [5]を測定した。 
次に，採血後に赤血球数打よび白血球数（計算板法）, 白血球百分比 (May-Giemsa 染色血液塗抹標本), へマ トクリット值 (毛細管遠沈法), へモグロビン量 (シア ンメトへモグロビン法), 血糖值 (GOD 法) を，血清分 離後に総蛋白量 (蛋白計), コステロール濃度 (kiliani 法), アルブミン濃度 (BCP 法), NEFA 濃度 (Duncombe 変法), MAO 活性 (色素基質法), 尿酸濃度 (炭 酸ナトリウム法) および $\mathrm{Na}^{+}$濃度, $\mathrm{K}^{+}$濃度 (炎光光度 計）を測定した。また，輸精管を Magnus 管に懸垂し， noradrenaline に対する $\mathrm{pD}_{2}$ および最大収縮を求めた。

振盪ストレス反復負荷ラットの外観上の変化は, 毛並 みが悪くなること以外には認められなかった。体重はス トレス負荷開始とともに減少し $5 〜 7$ 日で最低に達し， 2 週間後では正常ラットの $85 \sim 90 \%$ まで回復した。

振温ストレス最終負荷後の剖検に打いて，消化管の出 血および潰瑒は認められなかった。臟器の実重量を比較 するとストレス負荷群では, 心, 胸腺, 肝, 脾, 腎, 下 垂体重量の減少および副腎重量の増大が認められた。相 対重量では, 脳, 心, 肺, 睪丸, 副腎重量の増大打よび 下垂体重量の減少が認められた（Table 1)。これらの ことから心，肺は実重量で減少が，相対重量で增大が認 められ，体重の減少と平行しないことが観察された。一 方, 胸腺重量の減少扰よび副腎重量の増大は実重量, 相
対重量とも明らかに認められ，このことは振燙ストレス 負荷の影響をあらわしているものと考えられる。

この成績は, H. Selye[6]のいう非特異的ストレス症 状に相当し, 環境温度を周期的に変える SART ストレ ス負荷動物における観察の結果 [7]と一致した。

次に, 血液検査所見では, 赤血球数, ヘマトクリット 值およびへモグロビン量の変化はほとんど認められなか った。一方, 白血球数は有意な減少を示したが, 白血球 百分比には明らかな变化が慧められなかった (Table 2)。

血清の生化学值では血糖値の低下, NEFA 濃度の上 昇および $\mathrm{Na}^{+}$濃度の上昇と $\mathrm{K}^{+}$濃度の低下が認められ た。交感神経系の刺激により上昇することが報告されて いる尿酸濃度 $[8]$, アルブミン濃度[9]扑よびカテコール アミンの代謝促進を反映すると考えられる MAO 活性 には，変化が認められなかった(Table 3)。

振盪ストレス反復負荷ラットの肝グリコーゲン量打よ び副腎アスコルビン酸量では, 急性ストレス負荷後に観 察されたような増加 $[10,11]$ は認められず，正常ラット との差は認められなかった (Table 4)。

これらのことから，振擝ストレス反復負荷ラットに打 いては, 急性のストレス負荷後に一般に観察さ机る下垂 体一副腎皮質系抢よび交感神経一副腎髄質系の活動元進

Table 1. Influence of two weeks of repeated oscillation stress on organ weight in rats

\begin{tabular}{|c|c|c|c|c|c|c|c|}
\hline & & \multicolumn{2}{|c|}{ Absolute organ weight } & \multicolumn{4}{|c|}{ Relative organ weighta) } \\
\hline & & Control & $\begin{array}{l}\text { Oscillation } \\
\text { stress }\end{array}$ & \multicolumn{2}{|c|}{ Control } & \multicolumn{2}{|c|}{$\begin{array}{l}\text { Oscillation } \\
\text { stress }\end{array}$} \\
\hline \multicolumn{2}{|c|}{ No. of animals } & 13 & 13 & \multicolumn{2}{|c|}{13} & \multicolumn{2}{|c|}{13} \\
\hline Body weight & $(\mathrm{g})$ & $260.5 \pm 2.7$ & $227.6 \pm 2.7^{* *}$ & & & & \\
\hline Brain & $(\mathrm{mg})$ & $1717.2 \pm 9.6$ & $1713.1 \pm 10.6$ & $660.8 \pm$ & 7.8 & $755.4 \pm$ & $8.4^{* *}$ \\
\hline Hypophysis & $(\mathrm{mg})$ & $7.9 \pm \quad 0.3$ & $6.8 \pm 0.4^{* *}$ & $3.0 \pm$ & 0.1 & $3.0 \pm$ & 0.2 \\
\hline Heart & $(\mathrm{mg})$ & $693.2 \pm 9.2$ & $645.1 \pm 6.5^{* *}$ & $266.2 \pm$ & 3.0 & $283.9 \pm$ & $4.5^{* *}$ \\
\hline Thymus & $(\mathrm{mg})$ & $285.4 \pm 16.4$ & $206.9 \pm 7.9^{* *}$ & $109.5 \pm$ & 6.6 & $91.1 \pm$ & $3.7^{*}$ \\
\hline Lung & $(\mathrm{mg})$ & $989.2 \pm 29.4$ & $948.0 \pm 19.1$ & $380.2 \pm$ & 12.0 & $417.9 \pm$ & $12.1^{*}$ \\
\hline Liver & $(\mathrm{mg})$ & $8828.5 \pm 159.2$ & $7913.1 \pm 128.1^{* *}$ & $3388.5 \pm$ & 44.7 & $3474.6 \pm$ & 26.1 \\
\hline Spleen & $(\mathrm{mg})$ & $499.4 \pm 10.8$ & $441.7 \pm 15.0^{* *}$ & $192.8 \pm$ & 3.9 & $194.3 \pm$ & 2.4 \\
\hline Kidney & $(\mathrm{mg})$ & $1713.1 \pm 29.2$ & $1546.2 \pm 19.5^{* *}$ & $659.2 \pm$ & 9.8 & $680.0 \pm$ & 7.3 \\
\hline Adrenal & $(\mathrm{mg})$ & $39.0 \pm 1.1$ & $46.0 \pm 1.2^{* *}$ & $15.0 \pm$ & 0.4 & $20.2 \pm$ & $0.5^{* *}$ \\
\hline Testis & $(\mathrm{mg})$ & $2748.5 \pm 53.6$ & $2659.2 \pm 31.6$ & $1055.4 \pm$ & 16.7 & $1166.9 \pm$ & $9.4^{* *}$ \\
\hline
\end{tabular}

Each value represents a mean $\pm \mathrm{S}$. E.

a) : $\mathrm{mg} / 100 \mathrm{~g}$ body weight

* : Significantly different from control $(\mathrm{p}<0.05)$

** : Significantly different from control $(\mathrm{p}<0.01)$ 
Table 2. Influence of two weeks of repeated oscillation stress on hematological findings in rats

\begin{tabular}{lccc}
\hline & & Control & Oscillation stress \\
\hline \multicolumn{2}{c}{ No. of animals } & \multicolumn{1}{c}{13} & 13 \\
\hline RBC & $\left(\times 10^{4} / \mathrm{mm}^{3}\right)$ & $939.1 \pm 15.2$ & $932.5 \pm 18.8$ \\
WBC & $\left(\times 10^{2} / \mathrm{mm}^{3}\right)$ & $58.1 \pm 1.7$ & $49.2 \pm 1.2^{*}$ \\
Hematocrit & $(\%)$ & $46.3 \pm 0.4$ & $45.9 \pm 0.3$ \\
Hemoglobin & $(\mathrm{g} / 100 \mathrm{ml})$ & $16.7 \pm 0.6$ & $16.9 \pm 0.2$ \\
\hline Differential ratio of leucocytes & & \\
\hline \multicolumn{2}{c}{ No. of animals } & 12 & 13 \\
\hline Lymphocytes & $(\%)$ & $81.2 \pm 1.3$ & $78.0 \pm 1.7$ \\
Neutrophils & $(\%)$ & $16.1 \pm 1.3$ & $19.0 \pm 1.7$ \\
Monocytes & $(\%)$ & $2.2 \pm 0.3$ & $2.1 \pm 0.3$ \\
Eosinophils & $(\%)$ & $0.5 \pm 0.1$ & $0.8 \pm 0.1$ \\
Basophils & $(\%)$ & 0 & $0.2 \pm 0.1$ \\
\hline
\end{tabular}

Each value represents a mean $\pm \mathrm{S}$. E.

* : Significantly different from control $(p<0.05)$

Table 3. Influence of two weeks of repeated oscillation stress on serum biochemical values in rats

\begin{tabular}{llrc}
\hline & & \multicolumn{1}{c}{ Control } & Oscillation stress \\
\hline No. of animals & & \multicolumn{1}{c}{13} & \multicolumn{1}{c}{13} \\
\hline Glucose & $(\mathrm{mg} / 100 \mathrm{ml})$ & $110.72 \pm 1.08$ & $100.21 \pm 2.26^{* *}$ \\
Total cholesterol & $(\mathrm{mg} / 100 \mathrm{ml})$ & $51.18 \pm 1.44$ & $48.48 \pm 1.33$ \\
Total protein & $(\mathrm{g} / 100 \mathrm{ml})$ & $6.65 \pm 0.01$ & $6.56 \pm 0.04$ \\
NEFA & $(\mathrm{mEq} / 100 \mathrm{ml})$ & $0.31 \pm 0.04$ & $0.44 \pm 0.03^{* *}$ \\
Alubmin & $(\mathrm{g} / 100 \mathrm{ml})$ & $1.57 \pm 0.03$ & $1.59 \pm 0.03$ \\
Uric acid & $(\mathrm{mg} / 100 \mathrm{ml})$ & $1.65 \pm 0.05$ & $1.54 \pm 0.06$ \\
$\mathrm{MAO}^{*}$ & $(\mathrm{unit})$ & $5.75 \pm 0.83$ & $5.81 \pm 0.69$ \\
$\mathrm{Na}^{+}$ & $(\mathrm{mEq} / 1)$ & $141.31 \pm 0.60$ & $143.08 \pm 0.44^{* *}$ \\
$\mathrm{~K}^{+}$ & $(\mathrm{mEq} / 1)$ & $4.37 \pm 0.07$ & $4.14 \pm 0.07^{*}$ \\
\hline
\end{tabular}

Each value represents a mean $\pm \mathrm{S}$. E.

* : Significantly different from control $(\mathrm{p}<0.05)$

** : Significantly different from control $(\mathrm{p}<0.01)$

Table 4. Influence of two weeks of repeated oscillation stress on liver glycogen and adrenal ascorbic acid in rats

\begin{tabular}{|c|c|c|c|}
\hline & & Control & Oscillation stress \\
\hline No. of experiments & & 13 & 13 \\
\hline Liver glycogen & (mg/100 $\mathrm{g}$ wet tissue) & $2531.4 \pm 104.0$ & $2698.7 \pm 106.7$ \\
\hline Adrenal ascorbic acid & $(\mathrm{mg} / 100 \mathrm{~g}$ wet tissue) & $325.7 \pm 7.5$ & $300.2 \pm 10.8$ \\
\hline
\end{tabular}

Each value represents a mean $\pm \mathrm{S}$. E. 
Table 5. Influence of two weeks of repeated oscillation stress on maximum contraction of vas deferens induced by noradrenaline in rats

\begin{tabular}{lcc}
\hline & Control & Oscillation stress \\
\hline No. of experiments & 9 & 8 \\
\hline $\mathrm{pD}_{2}$ & $8.1 \pm 0.1$ & $7.9 \pm 0.1$ \\
Maximum contraction $(\mathrm{mm} / \mathrm{mg}$ dry tissue $)$ & $6.3 \pm 0.4$ & $7.9 \pm 0.7^{*}$ \\
\hline
\end{tabular}

Each value represents a mean $\pm \mathrm{S}$. E.

* : Significantly different from control $(\mathrm{p}<0.05)$

を反映する明らかな変化は，NEFA 濃度の上昇を除け ば認められず, 反復ストレス負荷の影響は急性ストレス 負荷のそれとは異なることが示唆された。

ところで, 柳瀬[12]は家免に緊縛ストレスを反復負荷 することにより,初期には血糖值の上昇が観祭されたが， 7 日以降になると認められなくなったとし, Mikulaj et al. [13]は，ラットに1日 3 時間の緊縛ストレスを長 期間負荷することにより，下垂体一副腎皮質系の内分泌 反応は, 初期にのみ恋められ, 長期間になるとこの反応 は抑制され，それとともに生体の諸機能も回復し，スト レス抵抗性が獲得されると主張している。一方，著者ら は先に振盪ストレス反復負荷ラットの血清グルココルチ コイド (11-OHCS) 量, GOT および GPT 活性を測定 し [4]，ストレス負荷 1 日では 11-OHCS 量が上昇する が，3日では逆に減少し，1週以降正常対照値にまで回 復すること, GOT および GPT 活性はストレス負荷 3 日まで上昇し，1週以降正常対照値に回復することなど を報告している。これらの報告や観祭は, 振盜ストレス 反復負荷ラットの赤血球数, ヘモグロビン量, ヘマトク リット值, 白血球百分比, 血清コレステロール, 血清蛋 白量, 血清アルブミン量, 血清尿酸量, 血清 MAO 活 性, 肝グリコーゲン量および副婜アスコルビン酸量にお いて，対照と同様な成績が得られたことと一致するもの と考えられ， 2 週間にわたる長期反復負荷後には，スト レスに対する抵抗性が，一部獲得されているものと推察 される。

次に, 交感神経支配臟器といわれる輸精管に㧊いて, 振盪ストレス反復負荷により noradrenaline に対する 最大収縮の増大が観察されたが， $\mathrm{p} \mathrm{D}_{2}$ に打いて差は認 められなかった（Table 5)。この成績から，ストレス 反復負荷による筋収縮系への影響が予想される。

以上のように， 2 週間の振嚍ストレス反復負荷ラット では, 胸腺重量の減少, 副腎重量の増大, 白血球数の減
少, 血糖值の低下, NEFA 濃度の上昇, $\mathrm{Na}^{+}$濃度の上 昇, $\mathrm{K}^{+}$濃度の低下执よび輸精管 noradrenaline のに 対する収縮の増大が認められた。これらの成績は, スト レスの負荷による交感神経一副腎䯣質系抢よび下垂体一 副腎皮質系の活動充進の結果によるものと推察される が, 他の血液検查所見, 肝グリコーゲン量および副腎ア スコルビン酸量では，正常ラットとの差は認められなか ったことから，一部には，ストレスに対する抵抗性が獲 得されているものと推察された。

\section{要 約}

掑食障害, 消化管分泌障害, 消化吸収障害をもち, 疲 学モデルとしても利用される振燙ストレス負荷動物の性 格を明らかにするため，ラットに振㴵ストレス（振幅 $13.5 \mathrm{~cm}, 130$ 往復/分, 3 時間/日）を 2 週間反復負荷し, 最終ストレス負荷の18時間後に臟器重量, 血液像, 血清 生化学值, 肝グリコーゲン量, 副腎アスコルビン酸量お よび輸精管の楽物反応性にみられる変化を検討した。

振燙ストレスの反復負荷により形態面では, 胸腺重量 の減少および副腎重量の増大が認められた。血液検査所 見としては白血球数の減少, 血糖值の低下, NEFA 濃 度の上昇, $\mathrm{Na}^{+}$濃度の上昇扰よび $\mathrm{K}^{+}$濃度の低下が，ま た輸精管の noradrenaline に対する反応は增大するこ とが認められた。これらの績成は, 交感神経一副腎髄質 系および下垂体一副腎皮質系の活動六進を示すものであ るが，他の血液検査所見，肝グリコーゲン量拉よび副腎 アスコルビン酸量では正常ラットと同様であり，一部に は，ストレスに対する抵抗性が獲得されているものと推 察された。

\section{文献}

[1] Takagi, K., Saito, H., Lee, C., and Hayashi, T. 
(1972), Japan. J. Pharmacol., 22, 17-26.

[2] 木下 㴊 - 堤 志津子・加藤正秀 (1982). 応用薬理, 24, (1), 149-155.

［3］小島 暁・佐藤 倜 - 殿内美佐子 - 加藤正秀 (1983). 応 用莧理, 25（6 ）, 931-937.

［4]佐藤 倜 - 小島 暁 - 唐沢久雄 - 殿内美佐子・堤 志津 子 (1980). 応用薬理, 20 ( 3 ), 425-439.

[5] Terada, M., Watanabe, M., Kunitomo, M., and Hayashi, E. (1978). Analytical Biochemistry, 84, 604-608.

[6] Selye, H. (1963). Nature, 138, 32.

[7] 米田良三・菅原國一・喜多富太郎・秦 多恵子・飯田順
子. 石田定廣 - 大場康寛 (1979). 応用薬理, 18 (4), 587596.

[8] Sumi, T., and Umeda, U. (1979). Japan. J. Pharmacol., 29, 661-663.

［9］切替辰哉 (1973). 薬局, 24（6）, 695-700.

[10] Eigler, N., Sacca, L., and Slerwin, R. S. (1979). J. Clin. Invest., 63, 114-123.

[11］青沼 繁・ 小浜靖弘・陳 英俊・屋敷伸治・江川 宏(1976). 薬学雑誌, 96 (11), 1313-1321.

[12］柳瀬昌弘 (1973). 日本生理誌, 35, 109.

[13] Mikulaj, L., and Mitro, A. (1970). Adv. exp. Med. Biol., 33, 631-638. 